\title{
The Training of Hatching Egg Skills as an Effort to Provide Kampong Chicken Seeds at Farmer Groups in Loa Village, Paseh District, Bandung Regency
}

\section{Pelatihan Keterampilan Penetasan Sebagai Upaya Penyediaan Bibit Ayam Kampung Pada Kelompok Tani Di Desa Loa, Kecamatan Paseh Kabupaten Bandung}

\author{
Endang Sujana*, Tuti Widjadtuti, Iwan Setiawan, Wiwin Tanwiriah, Dani Garnida, \\ Indrawati Yudha Asmara
}

Fakultas Peternakan, Universitas Padjadjaran, Indonesia

\begin{abstract}
Loa Village is one of the villages located in Paseh District, Majalaya, Bandung Regency. Loa Village has potential to be developed, in the field of animal husbandry. Many of the resident raising the chicken and duck in groups, but still use the traditional method, which is naturally hatching eggs by the hen so that it is difficult to get Kampong chicken seeds. With the village profile as above, we are challenged to provide the knowledge and techniques of raising Kampong chickens to Loa Village public, especially to farmer group members, through the virtual KKN-PPMD Padjadjaran University. The purpose of this activity is to increase the knowledge and skills of breeders in raising chickens, hatching eggs, composing the rations, processing chicken products and increasing the production of day old chicks. Apparently, the enthusiasm of the participants to gain knowledge and skills in raising Kampong chicken was quite high. Knowledge of the participants regarding the management of chickens, the preparation of rations are still lacking, but the enthusiasm of farmers to learn all the knowledge about raising Kampong chickens is very good, so that this activity can increase knowledge about how to hatch eggs and skills to operate the incubator and have a great passion for the business of Kampong chickens.
\end{abstract}

\begin{abstract}
Abstrak
Desa Loa merupakan salah satu desa yang berada di Kecamatan Paseh, Majalaya Kabupaten Bandung. Desa Loa memiliki potensi yang harus dikembangkan, salah satunya yaitu potensi di bidang peternakan. Banyak dari penduduknya yang merupakan kelompok peternak ayam dan entok, tetapi masih menggunakan cara trasional yaitu menetaskan telur secara alami oleh induk sehingga sulit mendapatkan bibit ayam kampung. Melihat profil desa seperti di atas, maka kami tertantang untuk memberikan pengetahuan tehnik beternak ayam kampung kepada para anggota kelompok tani melalui Kegiatan KKN-PPMD virtual universitas Padjadjaran kepada masyarakat Desa Loa khususnya kepada kelompok peternak. Tujuan dari kegiatan ini adalah untuk meningkatkan pengetahuan dan keterampilan peternak dalam budidaya beternak ayam, menetaskan telur, menyusun ransum, dan pengolahan hasil ternak ayam serta meningkatkan produksi anak ayam untuk bibit. Dari kegiatan ini antusiasme peserta untuk memperoleh pengetahuan dan keterampilan usaha budidaya beternak aym lokal cukup tinggi. Wawasan peserta mengenai tatalaksana pemeliharaan ayam, serta penyusunan ransum masih sangat kurang, tetapi animo peternak sangat baik untuk belajar semua pengetahuan tentang budidaya beternak ayam lokal, sehingga kegiatan ini dapat meningkatkan pengetahuan mengenai cara-cara menetaskan telur dan keterampilan mengoperasikan cara menetaskan telur dengan mesin tetas dan semangat untuk usaha beternak ayam kampung.
\end{abstract}

\footnotetext{
* Corresponding author:

E-mail address: endang.sujana@unpad.ac.id (Endang Sujana)
} 


\section{Pendahuluan}

Desa Loa Kecamatan Paseh, Majalaya memiliki kelompok peternak yang memelihara ayam dan entok, tetapi masih menggunakan cara tradisional, yaitu dengan melakukan penetasan secara alami yaitu dengan mengerami telur-telur ayam kampung oleh induk sehingga produktivitas hasil ternaknya rendah dan tidak dapat meningkatkan perekonomian masyarakat desa Loa, padahal permintaan telur ayam kampung dan daging ayam kampung maupun entok cukup tinggi.

Pertimbangan pemilihan kelompok ini berdasarkan pada kondisi kelompok ini sudah berjalan pada usaha peternakan ayam ayam broiler dan petelur yang menghasilkan produksi daging dan telur, namun para peternakan mengalami kesulitan yang kian menghimbit khususnya yang bergerak di bidang intensifikasi ayam mengalami kerugian. Pengaruh DOC, ransum dan obat- obatan yang sangat fluktuatif tanpa diikuti keseimbangan harga jual komoditas, akhirnya banyak peternak gulung tikar. Kelemahan yang terjadi berpangkal dari bibit tidak tersedia secara kontinyu, ransum dan obat-obatan yang harganya semakin melonjat. Oleh karena itu peternak yang tergabung dalam kelompok Tani Desa Loa ingin beralih usahanya dengan memelihara ayam kampung. Mereka berpendapat kalau memelihara ayam kampung akan jauh lebih menguntungkan karena selain dapat menjual telur juga dapat menjual ayam sebagai penghasil daging.

Ayam Kampung atau ayam lokal merupakan aset produksi yang sangat bermakna bagi kehidupan masyarakat terutama di Pedesaan, disamping sebagai pemenuhaan konsumsi daging dan telur, ayam kampung dapat berfungsi sebagai tabungan dan bermakna khusus sebagai pelengkap upacara perkawinan atau khitanan, bahkan kotorannya berperan sebagai pupuk. Harga daging dan telur ayam kampung diakui relatif lebih mahal, sehingga menjadi perangsang bagi peternak atau produsen untuk meningkatkan produktivitasnya (Mulando,2008). Usaha peternakan unggas lokal (Ayam kampung dan Itik) merupakan salah satu kegiatan komoditas perunggasan yang sudah lama dikenal masyarakat Indonesia.

Ayam lokal merupakan sumber protein hewani yang penting dan memberikan kontribusi ekonomi serta merupakan ternak tabungan bagi masyarakat perdesaaan (Widjastuti dkk,2016). Selain itu, ayam lokal berperan dalam socialkultural-religious masyarakat tertentu di Indonesia (Purba Sidadolog, 2007). Sebagian besar tenaga kerja yang digunakan untuk pemeliharaan ayam lokal adalah wanita atau ibu rumah tangga dari berbagai usia dengan pendidikan berbeda. Peranan pangan asal ayam lokal sangat penting dalam perbaikan gizi dan menjaga kesehatan masyarakat. Diketahui bahwa total rumah tangga di Indonesia sebesar 52,9 juta dimana 25 juta merupakan rumah tangga pertanian. Dari jumlah rumah tangga pertanian tersebut 60,9\% merupakan rumah tangga peternakan dan $98 \%$ nya merupakan unggas lokal. Data tersebut memberi gambaran bahwa ternyata hampir seluruh rumah tangga di pedesaan memelihara unggas lokal yang merupakan usaha budidaya rakyat (Direktotat Jenderal Peternakan dan Kesehatan Hewan, 2019).

Di pedesaan pemeliharaan unggas tersebut umumnya sebagai hewan ternak hanya sekedar hobi. Sistem tradisional lebih berfungsi selaku tabungan dan pelengkap kualitas gizi yang murah dan mudah. Namun demikian sumbangannya selaku penghasil protein hewani untuk masyarakat dan pendapatan cukup memberikan sumbangan nyata seperti telur dan daging (Nataamijaya, 2005). Keanekaragaman genetik ayam lokal merupakan aset penting dunia untuk kebutuhan manusia di masa depan (Cuc dkk., 2011; Faustin dkk., 2010). Secara khusus, ayam lokal di Indonesia mempunyai nilai strategis sebagai sumber pangan nasional. Namun demikian, peran ayam lokal di Indonesia sangat beragam dan merupakan bagian dari sejarah bangsa Indonesia (Purba Sidadolog, 2007).

Upaya kearah peningkatan performa ayam kampung tersebut perlu dilakukan atas pendekatan teknologi peternakan. Apabila dilakukan penyuluhan dan pelatihan maka membuka peluang untuk meningkatkan pendapatan masyarakat desa. Bentuk pengabdian yang akan dilakukan adalah pelatihan dengan memberikan beberapa materi yaitu : penyuluhan materi memilih bibit betina dan jantan yang baik untuk menghasilkan telur tetas, seleksi telur tetas, 
seleksi anak ayam, penyuluhan ransum yang baik untuk ayam bibit, penyuluhan cara menetaskan telur dengan mesin tetas, praktek cara menetaskan telur dengan mesin dengan video, praktek membuat mesin tetas sederhana. Pola pemeliharaan yang terkontrol dengan ketat dan tercatat dengan sistematis perlu dilangsungkan secara berkesinambungan. Peternak yang memperoleh pengetahuan dan keterampilan dalam membuat serta mampu menjalankan mesin tetas akan sangat menunjang keberhasilan suatu usaha.

Bila keseluruhan kegiatan program teknologi peternakan dapat diaplikasikan oleh anggota, maka sudah tentu pada waktu mendatang pendapatan mereka lebih meningkat. Agar usaha ternak ayam kampung pada kelompok Tani desa Loa melalui perbaikan teknologi peternakan dapat tercapai sesuai dengan rencana, maka dalam pelaksanaan penyuluhan dan keterampilan perlu didukung oleh tenaga sivitas akademi dosen Fakultas Peternakan Universitas Padjadjaran dan dibantu oleh mahasiswa universitas Padjadjaran yang sedang melakukan KKN kegiatan KKNPPMD.

\section{Metode / Methods}

\subsection{Kerangka Pemecahan Masalah}

Pada masa pandemi seperti sekarang ini mengharuskan semua orang untuk saling menjaga jarak atau social distancing. Kondisi ini dapat menghambat beberapa aktivitas sosial, salah satunya adalah pelaksanaan kegiatan Kuliah Kerja Nyata $(\mathrm{KKN})$. Berbeda dengan kegiatan KKN pada tahun-tahun sebelumnya yang dilakukan dengan mendatangi langsung lokasi kegiatan, pelaksanaan KKNM- PPMD tahun 2020 ini dilakukan melalui metode daring (secara online) dengan menggunakan media komunikasi online seperti Zoom dan Google Meet. Dengan menggunakan media komunikasi online memudahkan mahasiswa dan juga Dosen Pembimbing Lapangan untuk berkomunikasi tanpa harus bertatap muka secara langsung.

Kegiatan KKNM-PPMD ini juga dikombinasikan dengan kegiatan di lokasi. Kegiatan di lokasi dilakukan untuk survey lapangan yang akan dijadikan tempat untuk kegiatan. Kegiatan di lokasi juga dilakukan sesuai yang dibutuhkan dengan tidak terlalu sering datang ke lokasi dan tetap mematuhi protokol kesehatan seperti memakai masker, menggunakan hand sanitizer dan juga menjaga jarak.

Dalam metode yang digunakan, ada beberapa tahapan yang dilakukan dalam tahap pelaksanaan KKNM-PPMD Virtual yaitu:

\subsection{Realisasi Pemecahan Masalah}

\section{a. Tahap Persiapan}

Dalam tahap persiapan, mahasiswa dengan Dosen Pembimbing Lapangan melakukan koordinasi untuk programprogram yang akan dilaksanakan dalam kegiatan pengabdian masyarakat ini yang dipaparkan melalui chatting grup WhatsApp dan juga melakukan virtual meeting dengan menggunakan aplikasi zoom. Selain itu, anggota kelompok KKN yang terdiri dari 13 orang dibagi menjadi 3 kelompok kecil, yang beranggotakan empat sampai lima orang per kelompoknya. Tiap kelompok mengambil materi yang berbeda-beda, dengan melihat kondisi dan situasi dari lapangan maupun yang sedang terjadi saat ini.

\section{b. Tahap Pelaksanaan}

Dalam tahap pelaksanaan, tim KKN mengumpulkan data-data yang dibutuhkan dengan cara mewawancarai salah satu kelompok peternak dan juga melakukan survey terhadap kondisi lapangan yang akan menjadi tempat dilaksanakannya program kegiatan dari tim KKN. Survey lapangan itu sendiri hanya diwakilkan oleh beberapa anggota kelompok KKN. Pelaksanaan kegiatan disesuaikan dengan jadwal dari kelompok peternak itu sendiri. Waktu pelaksanaan ditentukan pada tanggal 12 Juli 2020 dan 19 Juli 2020 dengan bertempat di Desa Loa Kecamatan Paseh dengan pemaparan materi mengenai Pelatihan Keterampilan Penetasan pada Bibit Ayam Kampung. 


\section{c. Tahap Tindak Lanjut}

Setelah dilaksanakannya program kegiatan KKNM-PPMD oleh Tim, mahasiswa dan Dosen Pembimbing Lapangan juga melaksanakan koordinasi dan konsultasi tim melalui aplikasi zoom. Dalam hal ini, mahasiswa beserta Dosen Pembimbing Lapangan berkoordinasi mengenai teknis kegiatan yang akan dilaksanakan sesuai dengan intruksi dari Dosen Pembimbing Lapangan dan menyesuaikan dengan kebutuhan dari tempat pelaksanaannya.

\subsection{Khalayak Sasaran}

Yang menjadi khalayak sasaran kegiatan KKNM-PPMD ini adalah anggota Kelompok Tani desa Loa Kecamatan Paseh Majalaya Kabupaten Bandung dan Peserta Webinar.

\subsection{Pelaksanaan Kegiatan}

a. Tema : Pelatihan keterampilan penetasan dalam penyediaan bibit unggul ayam kampung melalui webinar.

b. Lokasi : Kampung Tiis Dingin, Desa Loa, Kecamatan Paseh, Majalaya.

c. Waktu : 5 Juli survei lapangan ke Desa Loa

12 Juli 2020, pelaksanaan webinar 1.

19 Juli 2020, pelaksanaan webinar 2.

\section{Hasil dan Diskusi}

\subsection{Pengetahuan Peternak Sebelum Penyuluhan}

Hasil analisa evaluasi awal dari jawaban pertanyaan kepada para peternak sebelum dilakukan penyuluhan adalah sebagai berikut :

- Pengetahuan peternak tentang budidaya ayam kampung secara umum masih kurang sehingga selalu mencoba apa yang dikatakan peternak yang lain yang kadang malah merugikan karena seringnya berganti-ganti cara pemeliharaan dan pemberian ransum.

- Pengetahuan peternak tentang penetasan telur ayam dengan mesin tetas, masih sangat kurang karena mereka sama sekali belum pernah menetaskan dengan mesin tetas walaupun dari mereka ada yang pernah melihat dan mendengar caranya.

\subsection{Persiapan dan Pelaksanaan Kegiatan}

Mekanisme kinerja dalam pelaksanaan KKNM- PPMD daring dan luring ini dilakukan dalam beberapa proses tahapan kegiatan. Mulai dari proses pembekalan oleh DPL secara daring, kemudian survei lokasi KKNM, pelaksanaan kegiatan, hingga proses penulisan laporan akhir. Kegiatan ini dilaksanakan dalam waktu 1 bulan. Terhitung dari akhir bulan Juni tanggal 24 sampai 31 Juli 2020, sementara bimbingan kepada peternak dilanjutkan sampai bulan November. Hasil koordinasi antara DPL dan Mahasiswa dibuat kegiatan yang dijadwalkan akan dilaksanakan dapat dilihat pada Tabel 1.

Tabel 1. Koordinasi dan Konsultasi dengan Tim dan Dosen Pembimbing Lapangan

\begin{tabular}{|c|c|c|c|c|c|}
\hline No & Bentuk kegiatan & Waktu & Tempat & $\begin{array}{l}\text { Pelaku dan } \\
\text { sasaran }\end{array}$ & Hasil \\
\hline 1. & $\begin{array}{l}\text { Pembekalan dan } \\
\text { pertemuan } \\
\text { perdana dengan }\end{array}$ & 24 Juni 2020 & $\begin{array}{l}\text { Via Zoom } \\
\text { Cloud } \\
\text { Meeting }\end{array}$ & $\begin{array}{l}\text { Dosen } \\
\text { Pembimbing } \\
\text { Lapangan dan } \\
\text { anggota }\end{array}$ & $\begin{array}{l}\text { Membahas kegiatan apa saja } \\
\text { yang akan dilakukan } \\
\text { selama KKNM satu } \\
\text { bulan ke depan dan penentuan }\end{array}$ \\
\hline
\end{tabular}




\begin{tabular}{|c|c|c|c|c|c|}
\hline No & Bentuk kegiatan & Waktu & Tempat & $\begin{array}{l}\text { Pelaku dan } \\
\text { sasaran }\end{array}$ & Hasil \\
\hline & DPL & & & KKNM & ketua kelompok. \\
\hline 2. & $\begin{array}{l}\text { Diskusi bersama } \\
\text { DPL dan Tim } \\
\text { PKM }\end{array}$ & 3 Juli 2020 & $\begin{array}{l}\text { Via Zoom } \\
\text { Cloud } \\
\text { Meeting }\end{array}$ & $\begin{array}{l}\text { DPL, Tim } \\
\text { PKM: Staf } \\
\text { dosen lab } \\
\text { produksi } \\
\text { ternak unggas } \\
\text { Fapet Unpad, } \\
\text { dan peserta } \\
\text { KKNM }\end{array}$ & $\begin{array}{l}\text { Membahas mengenai situasi } \\
\text { di lapangan yakni di Desa } \\
\text { Loa, Paseh, Kab. Bandung, } \\
\text { hingga memperoleh } \\
\text { keputusan bahwa harus ada } \\
\text { kegiatan luring di desa } \\
\text { tersebut, sesuai permintaan } \\
\text { masyarakat } \\
\text { peternak di sana. }\end{array}$ \\
\hline 3. & Survei lapangan & 5 Juli 2020 & $\begin{array}{l}\text { Rumah ketua } \\
\text { kelompok } \\
\text { peternak } \\
\text { Desa Loa }\end{array}$ & $\begin{array}{l}1 \text { dosen tim } \\
\text { PKM dan } 7 \\
\text { orang } \\
\text { perwakilan } \\
\text { anggota } \\
\text { KKNM }\end{array}$ & $\begin{array}{l}\text { Membahas kegiatan dengan } \\
\text { ketua kelompok peternak dan } \\
\text { melihat situasi secara umum } \\
\text { di sana. }\end{array}$ \\
\hline 4. & $\begin{array}{l}\text { Persiapan } \\
\text { webinar }\end{array}$ & 5 Juli 2020 & $\begin{array}{l}\text { Jalan Anyar, } \\
\text { Solokanjeru } \\
\text { k, Kab. } \\
\text { Bandung }\end{array}$ & $\begin{array}{l}7 \text { orang } \\
\text { perwakilan } \\
\text { anggota } \\
\text { KKNM }\end{array}$ & $\begin{array}{l}\text { Pembagian tugas seminar, } \\
\text { mendata semua kebutuhan } \\
\text { untuk seminar sekaligus } \\
\text { webinar dan membagi } \\
\text { tugas logistiknya. }\end{array}$ \\
\hline 5 & $\begin{array}{l}\text { Pelaksanaan } \\
\text { webinar } 1\end{array}$ & 12 Juli 2020 & $\begin{array}{l}\text { Rumah ketua } \\
\text { kelompok } \\
\text { peternak } \\
\text { Desa Loa }\end{array}$ & $\begin{array}{l}\text { Peserta } \\
\text { webinar, } \\
\text { peternak, } \\
\text { seluruh dosen } \\
\text { tim PKM } \\
\text { beserta DPL } \\
\text { dan anggota } \\
\text { KKNM }\end{array}$ & $\begin{array}{l}\text { Pelatihan Keterampilan } \\
\text { Penetasan pada Bibit Ayam } \\
\text { Kampung } 1\end{array}$ \\
\hline 6. & $\begin{array}{l}\text { Evaluasi webinar } \\
1\end{array}$ & 14 Juli 2020 & $\begin{array}{l}\text { Via Zoom } \\
\text { Cloud } \\
\text { Meeting }\end{array}$ & $\begin{array}{l}\text { Anggota } \\
\text { KKNM }\end{array}$ & $\begin{array}{l}\text { Mengapresiasi kegiatan, } \\
\text { membahas kekurangan } \\
\text { kegiatan, dan mencari } \\
\text { solusi untuk webinar } 2 .\end{array}$ \\
\hline 7. & $\begin{array}{l}\text { Persiapan } \\
\text { webinar } 2\end{array}$ & 16 Juli 2020 & $\begin{array}{l}\text { Via Zoom } \\
\text { Cloud } \\
\text { Meeting }\end{array}$ & $\begin{array}{l}\text { DPL dan } \\
\text { anggota } \\
\text { KKNM }\end{array}$ & $\begin{array}{l}\text { Membahas kebutuhan } \\
\text { webinar } 2 \text { dan } \\
\text { menyampaikan materi } \\
\text { yang akan dibawakan. }\end{array}$ \\
\hline 8. & $\begin{array}{l}\text { Pelaksanaan } \\
\text { webinar } 2\end{array}$ & 19 Juli 2020 & $\begin{array}{l}\text { Rumah ketua } \\
\text { kelompok } \\
\text { peternak } \\
\text { Desa Loa }\end{array}$ & $\begin{array}{l}\text { Peserta } \\
\text { webinar, } \\
\text { peternak, tim } \\
\text { dosen PKM } \\
\text { beserta DPL \& } \\
\text { anggota }\end{array}$ & $\begin{array}{l}\text { Pelatihan Keterampilan } \\
\text { Penetasan pada Bibit Ayam } \\
\text { Kampung } 2\end{array}$ \\
\hline
\end{tabular}




\begin{tabular}{|c|c|c|c|c|c|}
\hline No & Bentuk kegiatan & Waktu & Tempat & $\begin{array}{l}\text { Pelaku dan } \\
\text { sasaran }\end{array}$ & Hasil \\
\hline & & & & \multicolumn{2}{|l|}{ KKNM } \\
\hline 9 & $\begin{array}{l}\text { Evaluasi } \\
\text { penetasan }\end{array}$ & 30 Ju1i 2020 & $\begin{array}{l}\text { Ketua } \\
\text { kelompok } \\
\text { peternak desa } \\
\text { Loa }\end{array}$ & $\begin{array}{l}\text { peternak Desa } \\
\text { Loa, } \\
\text { perwakilan } \\
\text { dosen tim } \\
\text { PKM beserta } \\
\text { DPL \& } \\
\text { anggota } \\
\text { KKNM }\end{array}$ & $\begin{array}{l}\text { Penyerahan mesin tetas dari } \\
\text { oven bekas dan mesin tetas } \\
\text { buatan Fak. Peternakan dan } \\
\text { sejumlah telut tetas }\end{array}$ \\
\hline 10 & $\begin{array}{l}\text { Evaluasi hasil } \\
\text { penetasan }\end{array}$ & 15 Agustus 2020 & $\begin{array}{l}\text { Kelompok } \\
\text { peternak desa } \\
\text { loa }\end{array}$ & $\begin{array}{l}\text { Perwakilan } \\
\text { Tim PKM }\end{array}$ & $\begin{array}{l}\text { Memantau hasil penetasan } \\
\text { dengan menggunakan mesin } \\
\text { dari Lab. Produksi ternak } \\
\text { unggas Fapet }\end{array}$ \\
\hline 11 & $\begin{array}{l}\text { Evaluasi bulanan } \\
\text { budidaya } \\
\text { beternak ayam } \\
\text { kampung }\end{array}$ & 15 September 2020 & Tim PKM & $\begin{array}{l}\text { Anggota } \\
\text { Peternak desa } \\
\text { Loa }\end{array}$ & $\begin{array}{l}\text { Memantau cara kerja } \\
\text { budidaya ayam kampung }\end{array}$ \\
\hline 12 & $\begin{array}{l}\text { Evaluasi bulanan } \\
\text { budidaya } \\
\text { beternak ayam } \\
\text { kampung }\end{array}$ & 15 Oktober 2020 & Tim PKM & $\begin{array}{l}\text { Anggota } \\
\text { kontak Tani } \\
\text { desa Loa }\end{array}$ & $\begin{array}{l}\text { Memantau hasil penetasan } \\
\text { dengan mesin tetas dan } \\
\text { penangan DOC hasil } \\
\text { penetasan dengan mesin } t\end{array}$ \\
\hline 13 & $\begin{array}{l}\text { Evaluasi bulanan } \\
\text { budidaya } \\
\text { beternak ayam } \\
\text { kampung }\end{array}$ & 15 November 2020 & Tim PKM & $\begin{array}{l}\text { Ketua dan } \\
\text { anggota } \\
\text { kelompok tani }\end{array}$ & $\begin{array}{l}\text { Diskusi hasil budidaya ayam } \\
\text { kampung dan pamit selesai } \\
\text { bimbingan }\end{array}$ \\
\hline
\end{tabular}

Tanggal 3 Juli 2020

Diskusi bersama DPL dan Tim PKM, Via Zoom Cloud Meeting, membahas mengenai situasi di lapangan yakni di Desa Loa, Paseh, Kab. Bandung, hingga memperoleh keputusan bahwa harus ada kegiatan luring di desa tersebut, sesuai permintaan masyarakat peternak di sana.
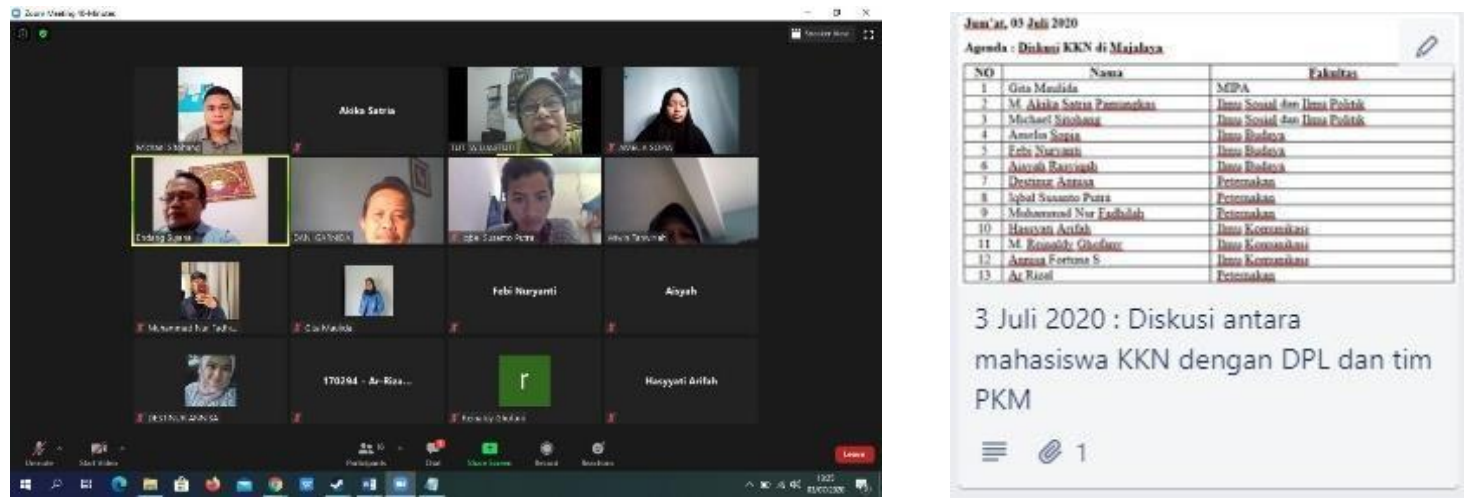
Tanggal 5 Juli 2020

Survei lapangan ke Rumah ketua kelompok peternak Desa Loa, bersama satu dosen tim PKM dan tujuh orang mahasiswa KKN, Membahas kegiatan dengan ketua kelompok peternak dan melihat situasi secara umum di sana. Setelah selesai dari kunjungan ke lokasi, kemudian dilanjut dilakukan pembagian tugas seminar, mendata semua kebutuhan untuk seminar sekaligus webinar dan membagi tugas logistiknya.
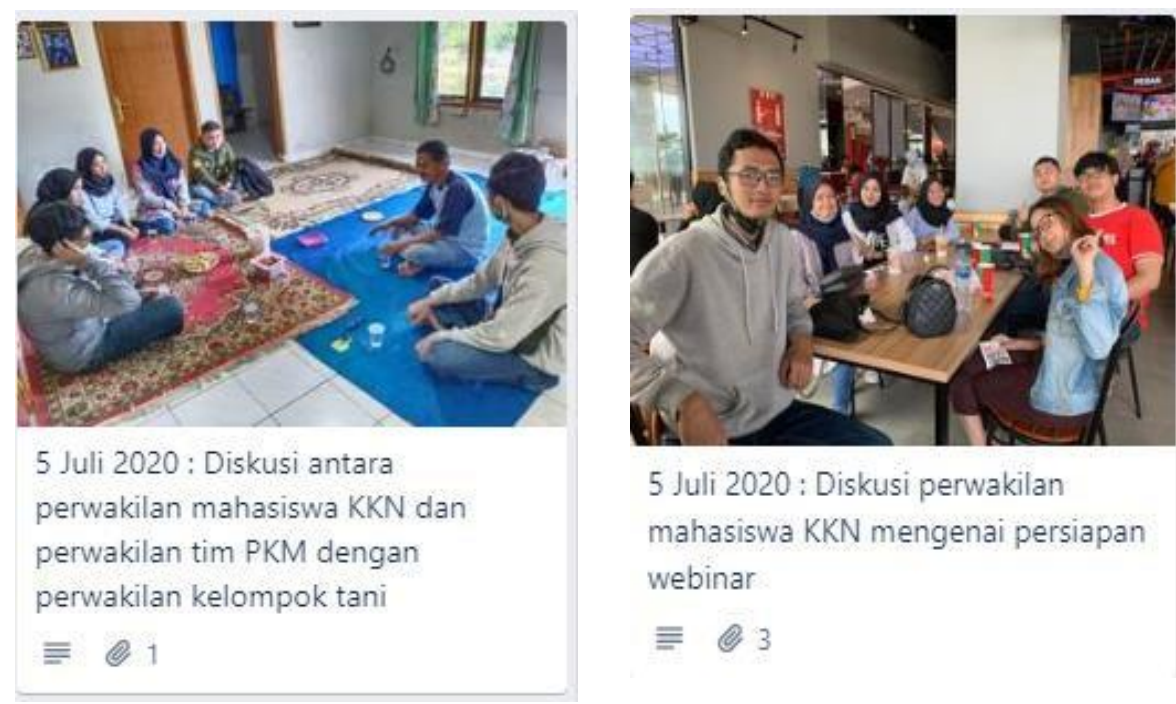

$$
\begin{aligned}
& 5 \text { Juli } 2020 \text { : Diskusi perwakilan } \\
& \text { mahasiswa KKN mengenai persiapan } \\
& \text { webinar } \\
& \equiv \text {. } 3
\end{aligned}
$$

Tanggal 9 Juli 2020

Melakukan pertemuan kembali melalui zoom antaran DPL, Tim PKM dan mahasiswa KKN untuk membicarakan acara webinar dan membuat poster untuk mengundang para peserta yang akan mengikuti penyuluhan keterampilan ayam kampung.

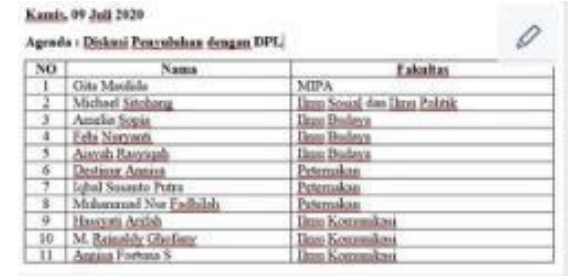

9 Juli 2020 : Diskusi mahasiswa KKN dengan DPL dan perwakilan tim PKM $\equiv 2$
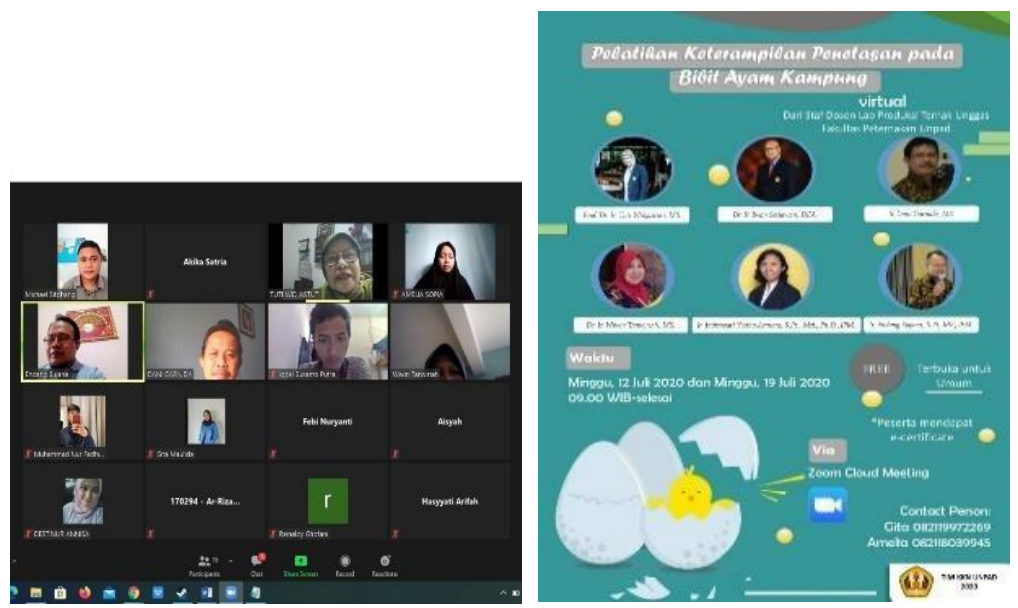

\subsection{Pelaksanaan Kegiatan KKNM- PPMD}

Tanggal 12 Juli 2020 
Kegiatan KKNM- PPMD ini dilaksanakan dua kali. Sebelum kegiatan dimulai, seluruh panitia dan peserta diarahkan untuk mengisi form kehadiran, pengecekan suhu badan, dan menggunakan hand sanitizer, serta duduk berjarak dalam rangka mengikuti protocol Kesehatan COVID-19. Pada tanggal 12 Juli pelaksanaan kegiatan penyuluhan, dibuka dengan pembacaan ayat suci Al-Quran, kemudian dilanjutkan dengan pengenalan moderator acara, yaitu Prof.Dr. Ir. Tuti Widjastuti, lalu dilanjutkan dengan pemaparan materi oleh Dr. Ir Wiwin Tanwiriah, MS., Ir Endang Sujana, S Pt, MP., IPM.dan Indrawati Yudha Asmara, mengenai Tata laksana pemeliharaan ayam lokal, materi Pemilihan bibit ayam kampung dan Pakan unggas serta diakhiri dengan sesi diskusi. Kegiatan ini dihadiri oleh 42orang peserta , terdiri dari peternak Majalaya dan peserta weinar.
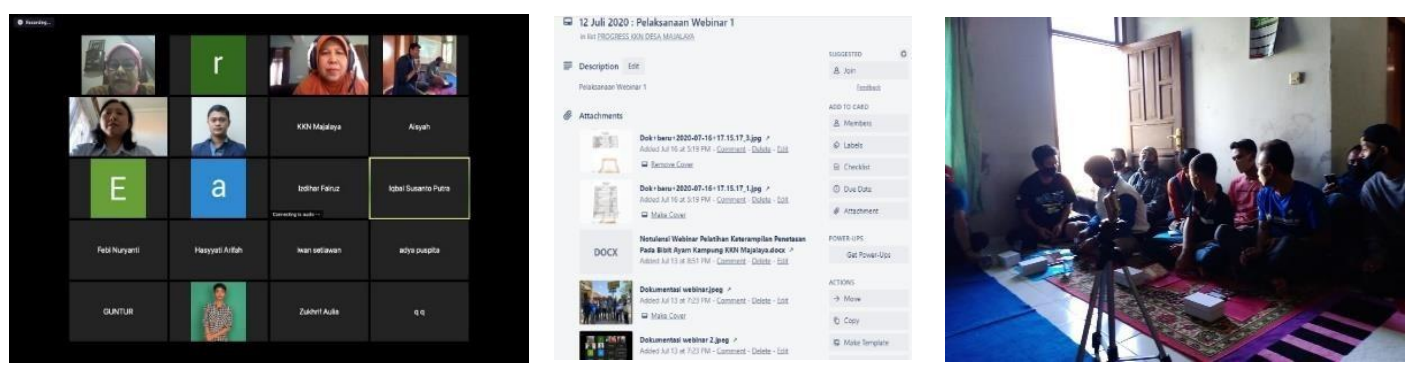

Tanggal 14 Juli 2020

Evaluasi webinar I, pertemuan dengan DPL, tim PKM dan mahasiswa KKN Mengapresiasi kegiatan, membahas kekurangan kegiatan, dan mencari solusi untuk webinar 2, Via Zoom Cloud Meeting.

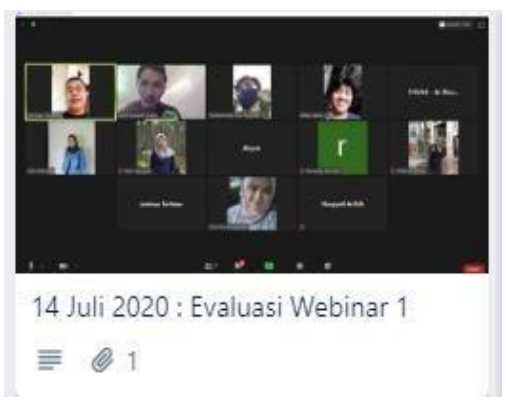

Tanggal 16 Juli 2020

Persiapan webinar 2 melakukan pertemuan Kembali antara Tim PKM dan mahasiswa Via Zoom Cloud Meeting , membahas kebutuhan untuk webinar 2 dan mengumpulkan materi-materi yang akan dibawakan pada acara webinar ke dua pada tanggal 19 Juli 2020.

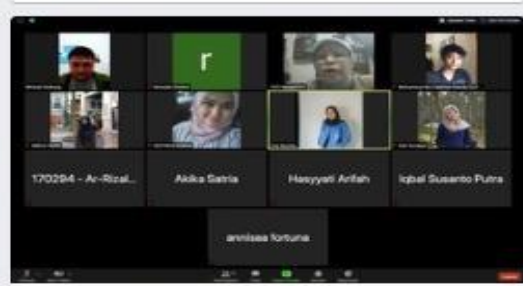

16 Juli 2020 : Diskusi Webinar 2 dengan DPL 
Tanggal 19 Juli 2020

Pada tanggal 19 Juli 2020, pelaksanaan kegiatan webinar kedua, dibuka dengan pengenalan moderator, kemudian dilanjutkan dengan pemaparan materi oleh Prof. Dr. Ir. Hj. Tuti Widjastuti, Ms., Dr. Ir. Wiwin Tanwiriah, Ms., Ir. Indrawati Yudha Asmara, Spt.,MSi., Ph.D., IPM., dan Ir. Dani Garnida, Ms.dengan materi Seleksi telur tetas, materi Fumigasi mesin dan telur tetas dan mengenai tatalaksana penetasan ,dan materi pembuatan mesin tetas melalui video yang bersumber dari youtube (https://bit.ly/buatmesintetas), dan diakhiri dengan sesi diskusi. Webinar kedua dihadiri oleh 43 orang peserta terdiri dari peternak Majalaya dan peserta webinar.
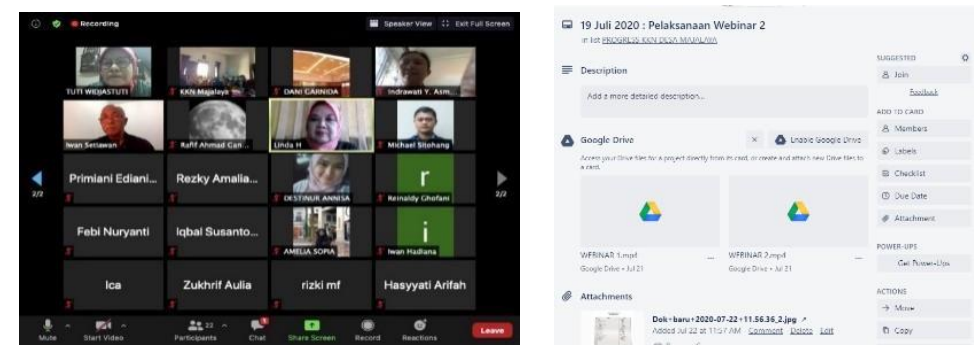

Tanggal 30 Juli 2020

Kegiatan selanjutnya yaitu melakukan pembuatan mesin tetas dari oven bekas yang dilakukan oleh mahasiswa KKN dan Tim PKL memnyerahkan mesin tetas yang dibuat oleh Staf Dosen Lab Produksi Ternak Unggas Fakultas Peternakan UNPAD juga menyerahkan telur tetas ayam kampung untuk ditetaskan dengan mesin tetas.
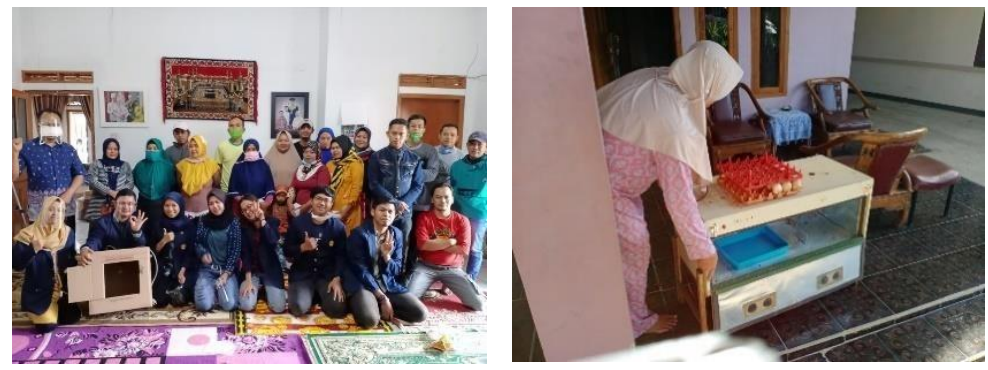

Agustus - November 2020

Melakukan kunjungan ke anggota kelompok Tani/Peternak desa Loa untuk berdiskusi mengenai teknik penetasan dan tatalaksana pemeliharaan ayam kampung. Dari hasil wawacara dengan kelompok mereka sudah paham cara menetaskan telur ayam dengan menggunakan mesin. Hasil yang diperoleh telur yang menetas sekitar $75 \%$ dari jumlah telur yang masuk. Untuk budidaya beternak ayam kampung sudah menerapkan cara beternak yang benar, memperhatikan kesehatan ayam dan juga sudah memanfaatkan tanaman herbal untuk pengobatan ayam-ayam yang sakit'

\subsection{Potensi Pengembagan Ayam Kampung}

Perkembangan ayam lokal di Indonesia tidak terlepas dari berbagai keunggulan yang dimiliki ayam ini. Pemeliharaan ayam lokal relatif mudah, murah dan tidak memerlukan lahan yang luas. Selain itu, ayam lokal relatif lebih tahan penyakit dibanding dengan ayam ras. Sartika dkk., (2011) melaporkan bahwa ayam lokal di Indonesia memiliki frekuensi gen Mx yang lebih tinggi dibanding ayam ras. Gen Mx ini merupakan gen yang berhubungan dengan ketahanan terhadap penyakit Avian Influenza (AI). Produk ayam lokal seperti daging dan telur memiliki pasar tersendiri sehingga dapat dikategorikan sebagai pasar premium. Ayam Kampung merupakan ayam lokal yang paling banyak dikenal masyarakat Indonesia. Daging ayam Kampung memiliki rasa yang lebih 
gurih dan tekstur yang berbeda dibandingkan dengan daging ayam ras. Telur ayam Kampung dipercaya masyarakat umum sebagai penambah stamina dan meningkatkan kesehatan tubuh. Setiap 100 gram daging ayam lokal seperti ayam Kampung mengandung air (74\%), protein (22\%), Kalsium (13 mg), Phospor (190 mg) dan Zat Besi (Fe) (1,5 mg) serta Vitamin A, C dan E. Telur ayam Kampung umumnya berwarna putih dan berukuran lebih kecil dibandingkan dengan telur ayam ras dengan berat antara 26,27-55,4 gram. $\mathrm{N}$ ilai gizi telur ayam Kampung per 100 gram telur mengandung kalori (189 kkal), lemak (11,5 g), protein (12,8 g), Kalsium (54 mg), Zat Besi (2,7 mg), Vitamin A (900 SI) (Dwiloka, 2003; Yuwanta, 2007). Menurut United States Department of Agriculture (USDA) (2000), telur ayam Kampung mengandung kolesterol lebih rendah dibanding telur ayam ras. Rata-rata ayam ras memiliki sekitar 423 miligram kolesterol per butir, sementara telur ayam Kampung hanya mengandung sekitar 277 miligram kolesterol per butir. Telur ayam Kampung mengandung asam lemak omega-3 dua kali lipat lebih tinggi dibanding telur ayam ras. Manfaat asam lemak omega-3 adalah untuk menjaga kesehatan jantung dengan membantu mengatur trigliserida dan menurunkan kadar kolesterol jahat. Selain itu, makronutrien kolin di dalam telur ayam Kampung berperan untuk mendukung kesehatan liver.

Pemeliharaan ayam lokal relatif mudah, murah dan tidak memerlukan lahan yang luas. Selain itu, ayam lokal relatif lebih tahan penyakit dibanding dengan ayam ras. Sartika dkk., (2011) melaporkan bahwa ayam lokal di Indonesia memiliki frekuensi gen Mx yang lebih tinggi dibanding ayam ras. Gen Mx ini merupakan gen yang berhubungan dengan ketahanan terhadap penyakit Avian Influenza (AI). Walaupun dipelihara dengan intensif, produktivitas ayam kampung sangat rendah apabila dibandingkan dengan ayam ras. Hal ini karena rendahnya mutu genetic serta kurangnya usaha perbaikan tatalaksana pemeliharaan. Angka kematian pada periode 0-12 minggu sebesar 20\% dan pada periode 0 - 16 minggu sebesar 29,8\% (Sulandari dkk, 2008). Ayam lokal memiliki pertumbuhan lambat dan produksi telur yang lebih rendah apabila dibandingkan dengan ayam ras. Selain itu, ayam lokal jarang dikembangkan secara komersial. Pemeliharaan ayam lokal masih tradisional dengan skala pemeliharaan yang rendah berbasis sumber pakan lokal dengan sentuhan teknologi yang masih terbatas. Ternak dipelihara sabagai sambilan dengan hasil produksinya sebagian untuk dijual dan sebagian untuk dikonsumsi sendiri. Tatalaksana pemeliharaan dilakukan dengan cara yang sederhana mengikuti tradisi yang berkembang di daerah setempat.

Salah satu kendala mengembangkan usaha ternak ini menjadi usaha berskala komersial adalah masih rendahnya dukungan industri sektor hulu, terutama di bidang peyediaan ternak (Day Old Chick (DOC)) dan pakan dalam jumlah dan harga yang layak untuk menunjang skala yang ekonomis. Peran ayam kampung, baru sebatas sebagai sumber telur, sedangkan dagingnya belum banyak dimanfaatkan, Ayam -ayam lokal yang ada ditangan masyarakat merupakan ayam tipe petelur. Sebagai penghasil telur, Ayam lokal tergolong cukup tinggi produksinya, oleh karenanya karakteristik bentuk badannya ramping serta kecil sementara perototan (daging) sangat rendah. Mengingat tuntutan akan daging ayam semakin besar dan ada kecenderungan untuk terus meningkat, maka tidak menutup kemungkinan untuk menjadikan peluang usaha ayam potong dengan memanfaatkan ayam jantan dengan sistem pemeliharaan intensif, dan dalam waktu 8 sampai 10 minggu sudah bisa dijual. Pemanfaatan ayam jantan sebagai sumber penghasil daging yang potensial dengan jalan pemeliharaan seperti ini masih jarang dilakukan. Pada hal ketersediaan ayam jantan cukup banyak dihasilkan saat penetasan. Peluang untuk memperoleh ayam jantan sebesar 50\%: 50\% artinya saat menetas rasio antara Jantan dan betina sama jumlahnya, sehingga peluang untuk memperoleh ayam jantan sangat besar.

\subsection{Upaya Solusi Mengatasi Masalah}

Penetasan adalah suatu cara yang membuat telur menetas menjadi anak. Penetasan bisa dilakukan secara alami atau buatan. Secara alami dilakukan oleh induk ayam atau induk entok. Adapun penetasan secara buatan adalah dengan menggunakan mesin tetas (Ensminger,1992). Untuk penyediaan anak ayam yang jumlahnya banyak agak sulit bila penetasan dilakukan secara alami, karena jumlah telur yang dapat dierami terbatas. Induk ayam kampung biasanya hanya bisa mengerami 12 butir telur itik, sedangkan induk entok bisa mengerami 14 - 20 butir telur ayam. Penetasan telur ayam dengan mesin tetas lebih praktis dan efisien dibandingkan penetasan secara alami, karena memiliki kapasitas lebih banyak dan dapat meningkatkan daya tetas. Pada dasarnya prinsip kerja mesin tetas adalah menggantikan sumber panas dari induk hewan pengeram (Jayasamudera dan Cahyono, 2005). 
Sebelum membuat mesin tetas, harus diperhatikan besarnya mesin tetas yang akan dibuat, jumlah anak yang menetas setiap minggu, jenis telur yang akan ditetaskan, tipe incubator, jenis mesin mau otomatis, semi otomatis atau manual, perhitungkan daya listrik yang dipakai dan sebagainya, Lalu rencanakan peralatan yang akan disusun. Demikian juga dengan telur tetas yang akan dieramkan harus telur yang berasal dari bibit yang baik, umur induk cukup, nutrisi induk terpenuhi, induk bebas penyakit dan sebagainya (North dan Bell, 1990).

Sebelum telur ditetaskan harus dilakukan seleksi telur supaya hasil penetasan maksimal. Beberapa hal yang perlu diperhatikan dalam seleksi telur adalah Besar telur, bentuk telur, warna kulit telur, kualitas kulit telur (tebal 0,28$0,33 \mathrm{~mm}$ ), kualitas interior telur (HU>80, ruang udara di ujung tumpul) yang dipengaruhi oleh lama penyimpanan, ransum dan lain. Setelah diseleksi pada telur tetas dilakukan sanitasi dengan membersihkan kotoran dengan cara diamplas sedikit lalu di lap dengan air hangat, dan untuk membunuh bakteri dilakukan fumigasi (cuci hama dengan gas). Caranya campurkan formalin $40 \%$ sebanyak 40cc dengan 20 gram KMnO4 untuk ruangan yang volumenya $2,83 \mathrm{~m}^{3}$ untuk $1 \mathrm{kali}$ konsentrasi dan biasanya yang dilakukan adalah 2 atau 3 kali konsentrasi (Kartasudjana, 2006).

Faktor yang penting dalam penetasan dengan mesin tetas diantaranya suhu, kelembaban, ventilasi, posisi telur dan pemutaran telur, candling dan pulling anak ayam (Ensminger, 1992). Untuk penetasan itik diperlukan suhu antara $38,5-41^{\circ} \mathrm{C}$ pada mesin tetas yang kecil (jenis still air machines incubator), sedangkan pada mesin tetas berukuran besar (jenis forced draft incubator) antara $35-38{ }^{\circ} \mathrm{C}$. Kelembaban relative mesin tetas dari minggu kesatu hingga ketiga (18 hari) pengeraman adalah adalah 60\%, sedangkan minggu keempat (18 - 21 hari) $85 \%$ (North and Bell, 1994). Perkembangan embryo membutuhkan oksigen pada tingkat normal yang ada di atmosfir yaitu $21 \%$, sedangkan pemutaran telur yang baik sebanyak $3-8$ kali per hari dari hari kedua hingga hari delapan belas supaya panas yang diterima telur lebih merata dan menghindari penempelan embryo pada membrane telur (Ensminger, 1992). Pengeluaran anak itik dari mesin tetas setelah lama inkubasi 21 hari dilakukan apabila bulu anak ayam sudah kering sekitar 95\%. Sebelum anak itik dipasarkan harus dilakukan seleksi yaitu dipilih yang sehat, tidak cacat, bentuk dan warna seragam dan lain. Ciri-ciri anak ayam yang baik adalah tubuh tegap, gesit, lincah, napsu makan tinggi, mata jernih, kaki kokoh, bulu bersih dan kering

\section{Kesimpulan}

Dari Pelaksanaan Kegiatan KKNM- PPMD dengan tema "Pelatihan Keterampilan Penetasan pada Bibit Ayam Kampung" di Desa Loa Majalaya, Kecamatan Paseh Kabupaten Bandung dapat disimpulkan bahwa:

- Pengetahuan anggota kelompok Tani desa Loa dalam budidaya ayam kampung secara umum dan pengolahan hasil produksi masih rendah, tetapi animo para peserta untuk menjadi peternak yang berhasil cukup besar.

- Setelah dilakukan penyuluhan, pengetahuan para peternak tentang budidaya beternak ayam kampung (budidaya ayam sentul, perkandangan, pemberian ransum, penetasan dan lain-lain) meningkat.

- Dari hasil evaluasi pre tes dan post test diperoleh hasil bahwa ada peningkatan pengetahuan pada peternak khususnya mengenai cara menetaskan telur dengan mesin tetas dan sudah mahir mengoperasikan, dan sudah mengenal bahan herbal yang dapat digunakan untuk mengobati ternak ayam kampung apabila sakit.

\section{Saran}

Dari hasil pengamatan di lapangan, kondisi peternakan ayam kampung secara umum di kelompok Tani di desa Loa, Kecamatan Paseh Majalaya, Kabupaten Bandung masih perlu diadakan penyuluhan dan bimbingan secara kontinyu baik dalam bidang budidaya ayam secara umum, penetasan dengan mesin tetas, maupun cara pengolahan hasil produksinya berupa telur dan dagingnya serta perkandangan dan penerapan biosekuriti. 


\section{Acknowledgements}

Ucapan terima kasih disampaikan kepada pimpinan Universitas Padjadjaran dan Fakultas Peternakan Unpad, dan mahasiswa KKNM Desa Loa Kecamatan Paseh Kabupaten Bandung.

\section{References}

Cuc, N.T.K., Weigend, S., Tieu, H.V., \& Simianer, H. 2011. Conservation priorities and optimum allocation of conservation funds for Vietnamese local chicken breeds. Journal of Animal Breeding and Genetics, 128: 284294.

Dwiloka, B. 2003. Efek Kolesterolmik Berbagai Telur. Media Gizi dan Keluarga 27(2):58-65.

Ensminger, M.E. 1992. Poultry Science. $3^{\text {rd }}$ Edition. The Interstate Printers \& Publishers. INC. Illinois.`1

Faustin, V., Adegbidi, Garnett, S.T., Koudande, D.O., Agbo, V. and Zander, K.K. 2010. Peace, health or fortune? preferences for chicken traits in rural Benin. Ecological Economics, 69: 1848-1857.

Jayasamudera, D.J. dan B.Cahyono. 2005. Pembibitan Itik. Jakarta: Penebar Swadaya.

Kartasudjana, R. dan E.Suprijatna. 2006. Manajemen Ternak Unggas. Jakarta: Penebar Swadaya.

Muladno, 2008. Local chicken genetic resources and production systems in Indonesia. Food and Agriculture Organization of the United Nations. Rome, Italy.

Nataamidjaya, A.G. 2005. Karakteristik Penampilan Pola Warna Bulu, Kulit, Sisik Kaki, dan Paruh Ayam Pelung di Garut dan Ayam Sentul di Ciamis. Balai Pengkajian dan Pengembangan Teknologi Pertanian. Bogor

North, M.O. \& Bell, D. D. 1990. Commercial Chicken Production Manual. New York: Van Nostrand Reinhold.

Sartika, T., Iskandar, S., Prasetyo, L. H., Takahashi, H., \& Mutsuru, M.. 2004. Kekerabatan Genetik Ayam Kampung, Pelung, Sentul dan Kedu Hitam dengan menggunakan Penenda DNA MIkrosatelit : I. Grup Pemetaan pada Makro Kromosom. Journal Ilmu Ternak dan Veteriner, 9(2): 81 - 86.

Sulandari, S., Zein, M.S.A., Paryanti, S., Sartika, T., Astuti, M., Widjastuti, T., Sujana, E., Darana, S., Setiawan, I. \& Garnida, D. 2006. Sumber Daya Genetik Ayam Lokal Dalam Keanekaragaman Sumber Daya Hayati Ayam Lokal Indonesia.

Standar Nasional Indonesia (SNI). 2002. Sistem pangan organik (SNI 01-6729- 2002). Badan Standarisasi Nasional, Indonesia.

Widjastuti, T., Adriani, L., \& Tanwiriah, W. 2016. Peningkatan Pendapatan Ibu- ibu PKK di Desa Tanjungsari dan Galura melalui Optimalisasi Usaha Beternak Ayam Kampung. Laporan Kegiatan PPMD Integratif, Direktorat Riset dan Pengabdian Kepada Masyarakat, Universitas Padjadjaran. 